\title{
Economic Empowerment of Haor Women through Duck Farming in Bangladesh
}

\author{
Romaza Khanum $^{1 *}$ and Muhammad Salim Al Mahadi ${ }^{2}$ \\ ${ }^{1}$ Department of Agricultural Economics and Policy, Sylhet Agricultural University, Sylhet; \\ ${ }^{2}$ Planning, Development and Works, Sylhet Agricultural University, Sylhet, Bangladesh \\ *Corresponding author and Email: payelsgvc@yahoo.com
}

Received: 16 March $2015 \quad$ Accepted: 06 June 2015

\begin{abstract}
A study was conducted to investigate the extent of women participation in duck rearing farm and to address women's economic empowerment in Hakaluki haor area of Maulvibazar district in Bangladesh. Primary data from 80 women duck raisers were collected through face to face interview. In this case haor women played an important role in the duck rearing activities which were carried out to explore the meaningful interpretation of women's present status. The result of the study revealed that duck rearing farming has exerted greater impact on improving socioeconomic condition and economic empowerment of haor women. The successful duck farming provides the women with economic independence and improved livelihood leading to their empowerment.
\end{abstract}

Keywords: Women participation, Hakaluki haor, economic empowerment, socioeconomic condition, improved livelihoods

\section{Introduction}

Women's contribution to agricultural development is enormous (Adeokun, 2000) and half of the world's food is used to be grown by them (Corrat and Ranson, 2000) as producers, distributors, processors, storers and marketers etc. But our society is still male-dominated and women's contributions to socioeconomic development are not visible due to a set of social norms (Bose et al., 2009). A study conducted by Hossain and Jaim (2014) showed that the lack of power or disempowerment is due to their less educational level and thus reflects in less income, less control over their own income, less bargaining power in selling their own produce and labour, less participation in decision making body, less access to production inputs and resources and employment opportunity than men. Thus, development practitioners are concerned to raise their empowerment level so that women are capable to challenge their dependency or oppressive situation in the family and society (Basu and Basu, 2001).

Women's empowerment is therefore, defined as "the capacity of women to be economically selfsufficient and self-reliant with control over decisions affecting their life options and freedom from violence" (Rao and Kelleher, 1995).

Duck farm can be a vital tool to improve women's status, households' food security, and employment opportunity. In Bangladesh, rural women feel more comfortable to participate in home-based income activities (Hossain and 
Bayes, 2009). Moreover, duck meat is highly demandable for people of all over Bangladesh which is also considered as low cost, easy to handle, highly productive, adaptability to stressful environmental conditions, comparatively more resistant to common diseases. It serves dual purpose-egg and meat, which accounts for about $6.34 \%$ (42.68 million) of total poultry population (270.71 million), occupying second place next to chicken in the production level (Bangladesh Economic Review, 2010, and 2012). Similarly, in the report of Food and Agriculture Organization (FAO), it is evident that the position of Bangladesh with respect to duck meat and egg production is $11^{\text {th }}$ and $4^{\text {th }}$, respectively among the Asian countries (Pingel, 2011).

An economic analysis of few studies conducted by Ghosh et al. (2012), Pervin et al. (2013), Khanum et al. (2005) revealed that low status of duck farmers seems to affecting duck productivity in different areas of Bangladesh. But still there is a lack of sufficient studies in haor $^{l}$ areas of Sylhet region, where a significant number of haor women were involved in duck rearing farm. It appears that inadequate or no systematic study (Alam et al., 2012; Huque et al., 1993; Huque and Sultana 2002) has been conducted on haor women's participation in intra-family decision making process in duck rearing farm.

Understanding of their income level, participation, and contribution to household decisions may provide evidence based information that might help the government to enrich formulation and implementation of appropriate policy for achieving their better livelihood patterns. Hence, the findings of the study may be helpful for policy makers to design

1 A back swamp or bowl-shaped depression located between the natural levels of rivers may comprise a number of beels of low lying water reservoirs, abundant marshy land and water logged areas. better duck farming options for achieving socioeconomic development as well as the formulation of effective women development policies. Such study may also help explain the theoretical background of women empowerment in the country. The present study was therefore undertaken aims to search the level of participation of haor women in duck rearing as well as level of women empowerment in intrahousehold decision making process.

\section{Materials and Methods}

\subsection{Study area and sampling}

In this study, the survey method was used. Four villages vig. Kandigaon, Radhanagar, Brahman Bazar and Routhgaon under Kulaura Upazila of Maulvibazar District were purposively selected. Twenty women duck raisers from each village were randomly selected and thus total sample size became 80 . The locale of the study belongs to Hakaluki haor area, highly favorable for duck rearing, specially for desi duck (Rana et al., 2010). The haor is the cheaper source of feed like aquatic weeds, various types of insects, tadpoles, earthworms, oyster's snail and crabs, a variety of small fishes, green forages etc. Different fallen grains are also other sources of nutrients for ducks (Ahmed, 1986) in those areas. Duck rearing is therefore, one of the major income generation opportunities. About $29 \%$ of the respondent's livelihood earning comes from selling duck and eggs in the area (Rana et al., 2010).

\subsection{Data collection and analysis}

Both primary and secondary sources of information were used for figuring the overall situation of women in duck rearing activities. The primary data were collected by means of a pre-tested and a set of well-structured interview schedule germane to the objectives of the study. The secondary information was collected from different published paper, report, BBS etc. Both closed and open-ended questions were used to see the economic impacts of duck rearing activities on women's household income, their 
savings, decision making power, and role of participation.

A group of participatory techniques like face to face interview and Focus Group Discussion (FGD) was used with the women duck raisers through check lists and finalized interview schedule after necessary changes, correction, modification and adjustment. Focus group discussions (FGD) were conducted to determine women involvement in home-based small farming and cross verify the information collected through interview schedule. A total of eight FGDs were conducted through two sessions in each village, comprising ten women duck raisers. The main information were collected from haor women consisting of educational level, age, occupational status, ownership of land, decision making process, economic empowerment and participation in duck rearing activities, and finally get their suggestions to improve duck rearing activities as well as increase supply of egg and meat. Data were collected during April to July 2013. Several visits were made for gathering data and information. The collected information were coded, tabulated and analyzed using appropriate statistical methods.

\subsection{Analytical techniques}

Different indices of analyses were employed to accomplish the objectives of the study. Two indices- participation index and women empowerment index were used to estimate the nature of participation in home-based farming activities and decision making process in haor area.

\subsubsection{Estimation of participation index (PI)}

To assess the nature of participation of women, all activities related to duck rearing were classified into 7 categories. Then women were asked to what extent they were involved in rearing activities. A 3-point rating scale was used to measure the extent of participation such as frequently, occasionally and never; and accordingly, scores of 2, 1 , and 0 were assigned, respectively. Thus, a woman participation score could range from 0 to 14 for 7 Duck Rearing Activities (DRAs). Participation Index of DRAs was estimated following Sheheli (2012) as:

Participation Index $(\mathrm{PI})=\sum_{i=1}^{7} R A F 5_{i}$

Where,

RAFS $_{\mathrm{i}}=$ Rearing Activity Frequency score

(2 = frequently, 1 = occavionaly, and $0=$ never $)$

$\mathrm{i}=$ Number of rearing activities ranged from

1 to 7.

\subsubsection{Determination of women empowerment index (WEI)}

Women Empowerment Index (WEI) was constructed in consideration of women participation in household decision making process in duck rearing and household related activities. In this regard, 16 household decision related activities were identified as indicators of WEI. Out of 16 decision related activities, three were duck rearing related, five were family matters related and eight were women mobility related. Three point rating scale was used to measure household decision activities in the following manner:

\begin{tabular}{lc}
\hline Household decision activities & $\begin{array}{c}\text { Score } \\
\text { assigned }\end{array}$ \\
\hline Decision taken by husband & 0 \\
$\begin{array}{l}\text { Decision taken by both husband } \\
\text { and wife }\end{array}$ & 1 \\
Decision taken by wife alone & 2 \\
\hline
\end{tabular}

In case of duck rearing related decision, women were asked who decides about i) purchasing/rearing duck, ii) duck treatment, and iii) selling eggs/duck etc. In case of family matters related decision; i) child education, ii) household assets, iii) savings, iv) coping crises, and v) marriage of daughter and boy etc. Similarly, in the case of women mobility related decision women were asked about ; i) different training programme, ii) bazar (marketing), iii) health centre or hospital, iv) social or political meeting, v) vote center, vi) upazila or zila offices, vii) attending social festival, viii) married women to their father's home or any other relative home etc. 
The average scoring value of $X_{i}$ (i.e. ith indicator) for all decision indicators would be the average of the value $K_{i}$ denoted by the following equation

$$
X_{i}^{-}=K_{i}^{-}
$$

The individual woman's empowerment index such as Women Empowerment Index of duck rearing related $\left(\mathrm{WEI}_{\mathrm{ei}}\right)$, Women Empowerment Index of family matters $\left(\mathrm{WEI}_{\mathrm{fi}}\right)$, and Women Empowerment Index of mobility $\left(\mathrm{WEI}_{\mathrm{mi}}\right)$, are given in equations 2, 3, and 4 respectively (Bose at el., 2009):

$$
\begin{aligned}
\mathrm{WEI}_{\mathrm{ei}} & =\frac{\sum_{\mathrm{i}=1}^{\mathrm{g}} x_{\mathrm{i}}}{3} . . \\
\mathrm{WEI}_{\mathrm{fi}} & =\frac{\sum_{\mathrm{i}=1}^{\mathrm{g}} x_{\mathrm{i}}}{5} . \\
\mathrm{WEI}_{\mathrm{mi}} & =\frac{\sum_{\mathrm{i}=1}^{\mathrm{N}} x_{\mathrm{i}}}{8} .
\end{aligned}
$$

Therefore, the overall $\mathrm{WEI}_{\mathrm{i}}$ stand for an ith indicator is shown in equation 5;

$$
\mathrm{WEI}_{\mathrm{i}}=\frac{(\text { WEIei +WEIfi +WEImi) }}{3}
$$

Again, to assess the individual empowerment status and position of haor women farmers, two randomly defined ranges were arranged as given below;

$$
\begin{aligned}
& \text { Not empowered } \mathrm{WEI}_{\mathrm{i}} \leq 1 \\
& \text { Empowered } \mathrm{WEI}_{\mathrm{i}}>1
\end{aligned}
$$

\section{Results and Discussion}

\subsection{Socioeconomic status of haor women}

The present profile of duck is summarized and presented in Table 1. It was found that $40 \%$ of the women respondents belonged to young aged group (20-35 years), followed by middle aged group $(39 \%)$. About $46 \%$ of duck raisers received primary education, only $10 \%$ of the respondents had secondary level of education, but $44 \%$ women in the study area were illiterate.

Table 1 also shows the marital status of the haor women. Most of them (49\%) were married, 30\% were widow and $21 \%$ divorced. In case of occupational status, $89 \%$ of the respondents were involved in duck rearing activities and this is the main source of income among haor women, followed by vegetable gardening (10\%), and small business women (1\%) with none as the service holders. It is also revealed that $99 \%$ of haor women were landless which only $1 \%$ had own land in which most of land was owned by male counterpart (husband/father) in the family.

\subsection{Participation in duck rearing activities (DRAs)}

Women participated in different activities of duck rearing, which were classified into 7 categories; i) putting \& take out of duck to shelter, ii) feeding and collecting snails/fish/earthworms etc., iii) cleaning of shed, iv) collecting of eggs, v) selling eggs/duck, vi) purchasing medicine for treatment. To assess extent of participation, women were asked as to what extent they were involved in all the selected DRAs. There were three options of their extent of participation which were: frequently, occasionally and never; score were assigned as 2 , 1 , and 0 respectively.

In Bangladesh, rural women mostly stay at home due to social custom which might be an important reason to more involvement in homebased agricultural/livestock /poultry activities rather than field level activities outside the home. However, considerable proportion of women duck raisers (about 56\%) frequently participates but only $10 \%$ of them never participate in shelter and shelter out of the ducks. On the contrary, $69 \%$ women were frequently participated in cleaning the shed while $84 \%$ had never involvement in selling eggs/ducks (Table 2). Findings also indicated no participation of women in purchasing medicine/going to doctor for treatment of the ducks, while about $44 \%$ of haor women duck raisers were participated occasionally in feeding \& collecting snails/ fish/earthworms and 14\% of them participated frequently. The overall findings of participation of haor women in duck rearing activities were more focused on home-based activities which are also supported by others (Bose et al., 2009). 
Table 1. Village wise percentage distribution of women duck raisers of Hakaluki haor area

\begin{tabular}{|c|c|c|c|c|c|}
\hline \multirow{2}{*}{$\begin{array}{l}\text { Characteristics of Women } \\
\text { Raisers }\end{array}$} & \multicolumn{4}{|c|}{ Selected study villages } & \multirow{2}{*}{$\begin{array}{l}\text { Average } \\
\quad(\%)\end{array}$} \\
\hline & $\begin{array}{c}\text { Khandigaon } \\
(\%)\end{array}$ & $\begin{array}{c}\text { Radhanagar } \\
(\%)\end{array}$ & $\begin{array}{c}\text { Braman bazar } \\
(\%)\end{array}$ & $\begin{array}{c}\text { Routhgaon } \\
(\%)\end{array}$ & \\
\hline \multicolumn{6}{|l|}{ Age } \\
\hline Young (20-35) & 45 & 35 & 50 & 30 & 40 \\
\hline Middle (36-50) & 35 & 50 & 30 & 40 & 39 \\
\hline Old (50 and Above) & 20 & 15 & 20 & 30 & 21 \\
\hline \multicolumn{6}{|l|}{ Educational level } \\
\hline Illiterate & 50 & 70 & 40 & 15 & 44 \\
\hline Primary & 40 & 30 & 35 & 80 & 46 \\
\hline Secondary & 10 & 0 & 25 & 5 & 10 \\
\hline \multicolumn{6}{|l|}{ Marital status } \\
\hline Married & 35 & 45 & 35 & 80 & 49 \\
\hline Divorced & 30 & 15 & 25 & 15 & 21 \\
\hline Widow & 40 & 35 & 40 & 5 & 30 \\
\hline \multicolumn{6}{|l|}{ Occupational Status } \\
\hline Duck rearing & 84 & 86 & 94 & 90 & 89 \\
\hline Service & 0 & 0 & 0 & 0 & 0 \\
\hline Business & 0 & 4 & 0 & 0 & 1 \\
\hline Vegetable gardening & 16 & 10 & 6 & 10 & 10 \\
\hline \multicolumn{6}{|l|}{ Ownership of cultivated } \\
\hline land & 98 & 100 & 100 & 99 & 99 \\
\hline Landless & 2 & 0 & 0 & 1 & 1 \\
\hline \multicolumn{6}{|l|}{ Own } \\
\hline \multicolumn{6}{|l|}{ Ownership of homestead } \\
\hline land & 100 & 100 & 100 & 97 & 99 \\
\hline Landless & 0 & 0 & 0 & 3 & 1 \\
\hline Own & & & & & \\
\hline
\end{tabular}

Source: Field survey, 2013

Table 2. Extent of participation of haor women in duck rearing activities

\begin{tabular}{lccc}
\hline Duck Rearing Activities (DRAs) & \multicolumn{2}{c}{ Percentage of women's participation in DRAs } \\
& \multicolumn{3}{c}{ (N=80) } \\
\cline { 2 - 4 } & Never & Occasionally & Frequently \\
\hline In shelter and shelter out of the ducks & $8(10)$ & $27(34)$ & $45(56)$ \\
Feeding and collecting snails/fish/earthworms & $34(42)$ & $35(44)$ & $11(14)$ \\
Cleaning of shed & $7(9)$ & $18(22)$ & $55(69)$ \\
Collecting of eggs & $2(3)$ & $24(30)$ & $54(67)$ \\
Selling eggs/duck & $67(84)$ & $8(10)$ & $5(6)$ \\
Purchasing medicine for treatment of duck & $80(100)$ & $0(0)$ & $0(0)$ \\
\hline
\end{tabular}

Note: Figures in the parentheses indicate percentages of total 


\subsection{Women empowerment in intra-family decision making process}

Women's participation in intra-family decision making process indicates that the democratic right exists among the family members and also shows better women empowerment status. Their economic contribution to the family income is important factor of participation in their intrafamily decision making process. In the study, there were sixteen indicators of decision to assess the degree of participation through asking to the haor women duck raisers whether the decision is taken by husband alone or husband and wife jointly or wife alone with respect to each of the activities as presented in the Table 3 . It revealed that almost in all cases, decision was taken by jointly by husband and wife as child education (about $71 \%$ ) and household assets $(66 \%)$ under family matters related decisions, respectively.

However, in a very few cases it was found that women participated alone particularly in the cases of marriage of daughter and boy (less than $1 \%$ ) as well as attending in social and political meeting (less than 1\%). Few expectations were also indicated the same scenario where husband was taken decision (less than 1\%) alone in the cases of attending in different training programmes, purchasing/repairing of household assets and married women move to their father's home or any other relative home related decision.

Table 3. Participation of women in decision making process

\begin{tabular}{|c|c|c|c|c|}
\hline \multirow[t]{2}{*}{ Indicators of Decision making } & \multicolumn{3}{|c|}{$\begin{array}{l}\text { Haor women in intra-household decision } \\
\text { making process }(\mathrm{N}=80)\end{array}$} & \multirow{2}{*}{$\begin{array}{c}\text { Average } \\
\text { Women } \\
\text { Empowerment } \\
\text { Index (WEI) }\end{array}$} \\
\hline & $\begin{array}{c}\text { Decision by } \\
\text { husband }\end{array}$ & $\begin{array}{l}\text { Decision by } \\
\text { husband and } \\
\text { wife jointly }\end{array}$ & $\begin{array}{l}\text { Decision } \\
\text { by wife }\end{array}$ & \\
\hline a) Duck Rearing Related & & & & 1.02 \\
\hline i) Purchasing/rearing duck & 8 & 19 & 53 & 1.56 \\
\hline ii) Duck treatment & 36 & 28 & 16 & 0.75 \\
\hline iii) Selling eggs/duck & 31 & 37 & 12 & 0.76 \\
\hline b) Family Matters Related & & & & 0.99 \\
\hline i) Child education & 11 & 57 & 12 & 1.01 \\
\hline ii) Household assets & 6 & 53 & 21 & 1.19 \\
\hline iii) Savings & 9 & 49 & 22 & 1.16 \\
\hline iv) Coping crises & 18 & 51 & 11 & 0.91 \\
\hline v) Marriage of daughter and boy & 32 & 43 & 5 & 0.66 \\
\hline c) Mobility Related & & & & 1.22 \\
\hline i)Different training programme & 2 & 11 & 67 & 1.81 \\
\hline ii) Bazar (marketing) & 17 & 29 & 34 & 1.21 \\
\hline iii) Health centre or hospital & 23 & 38 & 19 & 0.95 \\
\hline iv) Social or political meeting & 34 & 39 & 7 & 0.66 \\
\hline v) Vote center & 18 & 26 & 36 & 1.23 \\
\hline vi) Upazila or Zila offices & 9 & 31 & 40 & 1.39 \\
\hline vii) Attending social festival & 12 & 48 & 20 & 1.10 \\
\hline $\begin{array}{l}\text { viii) Married women to their father's } \\
\text { home or any other relative home }\end{array}$ & 7 & 38 & 37 & 1.40 \\
\hline Average decision Indicator $(a+b+c) / 3$ & & & & 1.08 \\
\hline
\end{tabular}

$\mathrm{N}=$ Number of respondents women raisers;

Empowerment status: Not empowered, if $\mathrm{WEI}_{\mathrm{i}} \leq 1$, and Empowered if $\mathrm{WEI}_{\mathrm{i}}>1$ 
Finally, Women Empowerment Index (WEI) has been calculated to understand the overall empowerment status of haor women in duck rearing, family matters, and their mobility related decisions. The WEIs as presented in Table 3 clearly indicated that women were empowered slightly above the average level in overall decision making activities. Bose et al. (2009) showed that the value of the empowerment index for women is generally low, indicating that women are seldom given the opportunities to express their ideas for execution. In the study, the findings showed that the average WEI was 1.08 that means haor women are empowered through economic contributions to their family income.

\section{Conclusions}

The study explored the present socioeconomic status, participation level in duck rearing, and empowerment of haor women in intra-household decision making process. It might be concluded that haor women were in more suitable position for duck rearing, who were also more experienced to have cash inflow to meet up the family needs through the age-old traditional practices. Recently, the growth performance of desi ducklings could be improved by supplementation of improved diets under scavenging system (Pervin et al., 2013) of duck rearing. Duck production is one of the promising sectors for empowering women to meet the family needs as well as commercial. The study revealed that haor women were more vulnerable in case of low educational level, landlessness in both cultivated and homestead, and limited scope of better occupational status.

It was evident that the most housewives were illiterate and were involved in duck rearing. The level of education, contribution to family income, increased participation in home based income generating activities and involvement in decision making process were important parameters indicating their improved empowerment. This implies that more interventions need to be undertaken by the public and private agencies to help the haor women get involved in duck rearing activities. This would serve as an incentive to them in the haor areas.

\section{References}

Adeokun, A. 2000. Women's Involvement in Fish Industry in Lagos State Nigeria. Unpublished $\mathrm{PhD}$ Thesis, Department of Agricultural Extension and Rural Development, University of Ibadan, Ibadan, Nigeria, 253 pp.

Ahmed, S. 1986. Duck Production In Bangladesh In Duck Production Science and World Practice. Farrel, D. J. and Stapleton, P. (Ed.), University of New England, Armidate, Australia, 342-350 pp.

Alam, M. B., Uddin, A. B. M. S., Bablu, M. A. Z. H., Kamaly, M. H. K., and Rahaman, M. M. 2012. Socio-economic Profile of Duck Farmers and Duck Management Practices in Rajshahi Region. Bangladesh Journal of Animal Science, 41(2): 96-105.

Basu, S. and Basu, P. 2001. Income Generation Program and Empowerment of Women-A Case Study in India. Charles Sturt University, Bathurst, NSW 2795, Australia,http://crawford.anu.edu.au/acde/ asarc/pdf/papers/conference/CONF2001_ 03.pdf. (Access on; 25/12/2014).

BER 2012. Bangladesh Economic Review, Ministry of Finance, Government of the People's Republic of Bangladesh, Dhaka. 92-93 pp.

BER 2010. Bangladesh Economic Review, Ministry of Finance, Government of the People's Republic of Bangladesh, Dhaka.

Bose, M. L., Ahmad, A. and Hossain, M. 2009. The Role of Gender in Economic Activities with Special Reference to Women's Participation and Empowerment in Rural Bangladesh. 
Gender, Technology and Development, Vol. 13 (1), January-April 2009.

Corrat, T. and Ranson, P. 2000. Women and Information for participation and Decision-making in Sustainable Development in Developing Countries. Background Paper for the Workshop on Gender Perspective for Earth Summit 2002, Available at the www.earthsummit2002.org/workshop.

Gosh, S., Haider, N. and Khan, M. K. I. 2012. Status of Households Duck Farmer and Their Associated Factors under Scavenging System in a Southern Area of Bangladesh International Journal of Natural Science, 2(4):108-112.

Hossain, M. and Bayes, A. 2009. Rural Economy and Livelihoods: Insights from Bangladesh. A. H. Development Publishing House, Bangladesh, https:// https://books.google.com/books/about/Rur al_Economy_and_Livelihoods.html

Hossain, M. and Jaim, W. M. H. 2011. Empowering Women to Become Farmer Entrepreneur: Case Study of a NGO Supported Program in Bangladesh. IFAD Conference on New Directions for Smallholder Agriculture, Rome, 24-25 pp.

Huque, K. S. and Sultana, N. 2002. Study on the Existing Duck Production Systems in Bangladesh. A report of Bangladesh Livestock Research Institute, Bangladesh.
Huque, Q. M. E., Ukil, M. A. and Hossain, M. J. 1993. Supplementary Feeding of Laying Ducks, under Scavenging Condition Bangladesh Journal of Livestock Research, 1: 57-62.

Khanum, J., Chwalibog, A. and Huque, K. 2005 Study on Rural Duck Production Systems in Selected Areas of Bangladesh. Livestock Research for Rural Development, Vol. 17 (10). Article \#113:http://www.cipav.org.co//rrd//rrd17/ 10/khan17113.htm (July 28, 2008).

Pervin, W., Chowdhury, S. D., Hasnath, M. R., Khan, M. J., Ali, M. A. and Raha, S. K. 2013. Duck Production Strategy and Profile of Duck Farmers in the Coastal Areas of Bangladesh. Livestock Research for Rural Development, Vol. 25. Article \#129.http://www.lrrd.org/lrrd25/7/perv25 129.htm

Pingel, H. 2011. Waterfowl Production for Food Security. Lohman Information, 46:34-37.

Rana, M. P., Shohel, M. S. I., Akter, S. and Alam, M. S. 2010. Haor Based Livelihood Dependency of Rural Community: A Study on Hakaluki Haor in Bangladesh. Proceeding of the Pakistan Academy of Sciences, 47 (1):1-10.

Rao, A. and Kelleher, D. 1995. Engendering Organizational Change: The BRAC Case. World Development, Vol. 24 (1).

Sheheli, S. 2012. Improving Livelihood of Rural Women Through Income Generating Activities in Bangladesh. $\mathrm{PhD}$ Dissertation, Division of Agricultural Economics, Humboldt University, Berlin. 